Volume: 6

Nomor : 4

Bulan : November

Tahun : 2020

\title{
Penggunaan Diksi pada Berita Kriminal Koran Harian Gorontalo Post
}

\author{
Nuryati Setu \\ Asna Ntelu \\ Salam \\ Universitas Negeri Gorontalo \\ Pos-el: nuryati.0598@gmail.com \\ asnantelu01@gmail.com \\ salamtolaki@ung.ac.id
}

DOI: 10.32884/ideas.v6i4.299

\begin{abstract}
Abstrak
Tujuan penelitan adalah: (1) mendeskripsikan diksi yang digunakan pada berita kriminal koran harian Gorontalo Post; dan (2) mendeskripsikan makna diksi yang terdapat pada berita kriminal tersebut . Teori yang digunakan dalam penelitian ini adalah teori diksi dan makna. Dalam penelitian ini, digunakan metode deskriptif untuk menggambarkan tentang penggunaan diksi dan makna diksi yang terdapat dalam berita kriminal. Teknik pengumpulan data adalah teknik dokumentasi, baca, dan catat. Teknik analisis data yang digunakan dalam menyelesaikan penelitian adalah: (1) mengidentifikasi data yang termasuk diksi dalam berita kriminal koran harian Gorontalo Post;(2) menginterpretasikan berdasarkan data yang ditentukan terhadap diksi tersebut; (3) mengklasifikasikan data yang telah didapatkan terkait diksi tersebut;dan (4) membuat atau menyusun terhadap hasil data diksi tersebut. Hasil penelitian dan pembahasan dalam berita kriminal koran harian Gorontalo Post: (1) pertama, diksi yang terdapat dalam berita kriminal, yaitu kata umum, kata khusus, kata populer dan kata jargon. Penggunaan diksi secara bervariasi telah dipakai sesuai dengan konteks yang ada dalam berita; (2) kedua, makna yang terdapat dalam berita kriminal koran harian Gorontalo Post, yaitu makna konotatif, makna leksikal, dan makna gramatikal. Makna kata tersebut membuat informasi yang disampaikan kepada pembaca menjadi lebih jelas. Penggunaan diksi dalam berita kriminal yang tepat telah menyampaikan makna sesuai konteks yang ada dan mudah dipahami pembaca.
\end{abstract}

\section{Kata Kunci}

Penggunaan diksi, berita kriminal, makna

\begin{abstract}
The research objectives are: (1) to describe the diction used in the criminal news of the Gorontalo Post daily newspaper; (2) to explain the meaning of diction in the criminal news of the Gorontalo Post daily newspaper. The theory used in this research is the theory of diction and types of meaning. In this study, a descriptive method is used to describe the use of diction and the meaning of diction contained in criminal news. Data collection techniques are documentation, reading, and note-taking techniques. The data analysis techniques used in completing the research were: (1) identifying data including diction or choice of words in the criminal news of the Gorontalo Post daily newspaper;

(2) interpreting based on determining data on diction in the criminal news of the Gorontalo Post daily newspaper; (3) classifying the data that has been obtained related to diction; and(4) making or compiling the results of diction $r$. The research results in the criminal news
\end{abstract}


of the Gorontalo Post daily newspaper: (1) first, diction contained in criminal news, namely general words, special words, popular words and jargon words. Various diction has been used according to the context in the news; (2) second, the meaning contained in the criminal news of the Gorontalo Post daily newspaper, namely the connotative meaning, the lexical meaning, and the grammatical meaning. The meaning of the word makes the information conveyed to the reader clearer. The proper use of diction in criminal news has conveyed the definition according to the existing context and is easily understood by the reader.

Keywords

Use of diction, crime news, meaning

\section{Pendahuluan}

Bahasa merupakan salah satu sarana untuk berkomunikasi atau memberikan informasi kepada khalayak. Menurut Hidayatullaah (2018: hlm. 41) dalam jurnal "Analisis Kesalahan Diksi pada Karangan Siswa kelas IX SMP Islam Daar El-Arqam Tangerang”, dengan bahasa, manusia dapat menyatakan sikap, menyampaikan ide, pikiran, perasaan, dan pandangannya kepada orang lain yang dapat dilakukan secara lisan maupun tertulis. Dalam kehidupan sehari-hari, orang cenderung menggunakan bahasa lisan. Contohnya, bercerita, ceramah, maupun mengajar di dalam kelas dan sebagainya. Bahasa tulisan merupakan sesuatu yang dihasilkan melalui penggabungan kata demi kata sehingga menjadi sebuah kalimat yang dijadikan sebagai informasi dan ditulis dengan bahasa menarik. Contoh bahasa tulis untuk mendapatkan informasi yaitu melalui koran, majalah, tabloid dan sebagainya.

Koran memperlihatkan informasi dalam berita secara realitas dari berbagai sumber peristiwa yang telah terjadi di sekitar kehidupan. Menurut Badara, (2012: hlm. 8), surat kabar/media menyusun realitas dari berbagai peristiwa yang terjadi hingga menjadi cerita atau wacana yang bermakna. Peristiwa tersebut ditulis dan disusun dengan kata-kata yang baik dan mudah untuk dipahami. Menurut Sarwoko (2007: hlm. 72), pilihan kata atau diksi bukan hanya soal pilih-memilih kata, melainkan lebih mencakup bagaimana efek kata tersebut terhadap makna dan informasi yang ingin disampaikan.

Seorang penulis harus menguasai kosakata sehingga tulisan dapat memberikan ide ataupun informasi terkait berita terutama dalam penyampaian makna yang baik bagi pembaca. Menurut Djasasudarma (2012: hlm. 7), makna adalah pertautan yang ada di antara unsurunsur bahasa itu sendiri (terutama kata-kata). Makna merupakan arti yang terkandung dalam suatu tulisan atau pembicaraan yang ditujukan saat menulis maupun berbicara terhadap seseorang.

Pilihan kata merupakan satu unsur sangat penting, baik dalam dunia karang mengarang maupun dalam dunia tutur setiap hari (Arifin dan Amran Tasai, 2009: hlm. 28). Dalam 
Volume: 6

Nomor : 4

Bulan : November

Tahun : 2020

menulis berita, penulis harus memerhatikan dalam pemilihan kata agar informasi yang disampaikan lebih jelas. Pilihan kata yang baik akan menarik perhatian pembaca.

Gorontalo Post merupakan sebuah media penerbitan koran yang ada di kota Gorontalo. Koran tersebut memuat berita-berita yang beragam seperti berita di bidang politik, ekonomi, kriminal, olahraga, pendidikan, dan lain-lain..

Pilihan kata sangat berguna untuk diteliti dalam berita kriminal koran harian Gorontalo Post karena pilihan kata sebagai bahasa yang digunakan jurnalis dalam menulis berita untuk disampaikan kepada khalayak.

Pilihan kata yang berlebihan, ambigu, dapat membuat membuat makna dalam kata tidak tersampaikan dengan baik. Hal itu menyebabkan, berita yang ditullis tidak dapat dipahami pembaca. Diksi yang dimaksud dalam penelitian ini adalah pemilihan kata yang telah digunakan junalis dalam menulis berita kriminal koran harian Gorontalo Post dan makna yang terkandung dalam penggunaan pilihan kata tersebut.

\section{Metode Penelitian}

Metode penelitian adalah sesuatu cara dalam memecahkan suatu persoalan atau pokok masalah yang akan diteliti. Metode yang digunakan dalam penelitian ini adalah metode deskriptif. Data yang digunakan dalam penelitian ini adalah kata yang ada dalam berita kriminal koran harian Gorontalo Post berupa diksi atau pilihan kata. Sumber data diperoleh dari naskah koran harian Gorontalo Post dalam berita kriminal dari edisi 2 Januari 2020 sampai 31 Januari 2020. Teknik pengumpulan data dilakukan melalui dokumentasi, baca dan catat. Setelah itu, langkah-langkah yang digunakan untuk menganalisis data yaitu: (1) mengidentifikasi data yang termasuk diksi atau pilihan kata dalam berita kriminal koran harian Gorontalo Post, (2) menginterpretasikan data, (3) mengklasifikasi data yang telah didapatkan, dan (4) membuat atau menyusun data.

\section{Hasil dan Pembahasan}

Berdasarkan data yang diperoleh dari berita kriminal koran harian Gorontalo Post, hasil penelitian tentang penggunaan diksi yang diperoleh dari naskah berita kriminal koran harian Gorontalo Post mulai 2 Januari sampai dengan 31 Januari 2020 dapat dijabarkan sebagai berikut. 


\section{Diksi yang Digunakan dalam Berita Kriminal Koran Harian Gorontalo Post}

Penelitian ini membahas penggunaan diksi dalam berita kriminal koran harian Gorontalo Post. Jenis-jenis diksi yang dikaji dalam berita kriminal, yaitu kata umum, kata khusus, kata popular, dankata jargon.

\section{Kata Umum}

Kata umum merupakan sebuah kata yang sering digunakan dan memiliki cakupan makna kata yang luas. Berdasarkan analisis data yang telah dilakukan, penggunaan diksi dalamberita kriminal terdapat kata umum yang digunakan. Penulisan kata umum dalam berita kriminal yakni sebagai berikut.

"Marni mengaku belum sempat melaporkan peristiwa tersebut kepada pihak berwajib, rasa panik dan langsung melarikan anaknya kerumah sakit menjadi prioritasnya," (GP, 2020 2/1).

Dalam penggalan berita ini terdapat kata 'pihak berwajib' yang termasuk kata umum karena belum diketahui secara pasti peristiwa tersebut akan dilaporkan kepada pihak yang mana. Bisa saja peristiwa tersebut dilaporkan kepada satpam, polisi, ataupun tentara. 'Rasa panik' merupakan kata umum sebab memiliki banyak maka yang terkandung dalam kata tersebut, seperti bingung, gugup, atau takut secara tiba-tiba yang dirasakan seseorang. Rasa panik tersebut dirasakan Marni ketika membawa anaknya di rumah sakit.

"Sebelum pulang, Yusuf merasa curiga dengan kantong plastik warna kuning yang terselip di dalam helem, saat dibuka ternyata sosok bayi mungil yang melengkung di helem tersebut," (GP, 2020 2/1).

Pada kutipan berita di atas terdapat kata 'mungil' yang memiliki makna dalam KBBI V yaitu kecil elok molek atau lucu, Kata 'mungil' pada berita untuk memberikan penjelasan terkait bayi yang masih kecil belum lama dilahirkan.

"Merasa panik, Yusuf sontak berlari ke rumah warga lainnya, serta memberitahu perihal penemuannya," (GP, 2020 2/1).

Penggalan berita di atas menggunakan kata 'rumah' yang maknanya adalah bangunan untuk tempat tinggal atau bangunan pada umumnya (KBBI V). Makna 'rumah' di atas adalah bangunan yang dijadikan tempat tinggal oleh masyarakat.

"Padengo-Masyarakat yang ada di desa Padengo, kecamatan Limboto Barat, Kabupaten Gorontalo, dibuat heboh, dengan penemuan sesosok mayat yang belakangan diketahui berprofesi sebagai tukang bentor," (GP, 2020 3/1). 
Volume: 6
Nomor : 4
Bulan : November
Tahun : 2020

E-ISSH: 2656-940X

P-ISSH: 2442-367K

URL:jurnalididesspublishing.co.id

Dalam kutipan di atas, terdapat kata 'heboh' yang memiliki cakupan makna yang sangat luas. Kata 'heboh' merupakan kata umum karena mengandung banyak makna dapat diuraikan secara terperinci seperti gaduh, ribut, gempar (KBBI V).

"Hingga akhirnya, ditemukan tak bernyawa. Polisi menduga, Basri tewas dengan cara tak wajar, lantaran dari fisik korban, ditemukan sejumlah luka," (GP, 2020 $3 / 1)$.

Pada kutipan di atas, terdapat kata 'tewas' makna katanya berdasarkan KBBI V dibagi menjadi dua, yaitu sebagai verba dan verba ragam cakapan. Kata tewas sebagai verba memiliki makna mati. Namun, dalam ragam cakapan, maknanya adalah kalah, cela, salah (luput), kekurangan (sesuatu yang kurang baik). .

Kata-kata umum yang terdapat pada data : pihak berwajib, rasa panik, mungil, rumah, heboh, dan tewas. Kata-kata tersebut digunakan untuk menyampaikan informasi secara singkat, jelas, dan mudah dipahami. Seperti pendapat Romli (Badara, 2012: hlm. 24-25) tentang karateristik bahasa jurnalistik, salah satunya adalah menyampaikan informasi dalam berita harus singkat, jelas, dan sederhana.

2. Kata Khusus

Kata khusus merupakan kata-kata yang cakupan maknanya lebih sempit atau tidak secara umum. Berdasarkan dari hasil analisis data yang telah dilakukan dalam penggunaan diksi pada berita kriminal, terdapat kata khusus yang digunakan. Penggunaan kata khusus dalam berita kriminal yakni sebagai berikut.

"Gorontalo-Keterlibatan oknum Aparatur Sipil Negara (ASN) dalam peredaran dan penyalahgunaan narkoba di Gorontalo tidak pernah ada habisnya. Padahal, ancaman hukuman mati bagi pengedar narkoba sudah terbukti," (GP, 2020 2/1).

Pada kutipan berita tersebut, terdapat kata 'oknum' yang maknanya orang atau anasir (dengan arti yang kurang baik).

"Informasi yang dirangkum Gorontalo Post, penangkapan terhadap RM dilakukan saat pria berbadan ramping ini ketika hendak mengambil barang kiriman di pelabuhan penyeberangan Kota Gorontalo. Ternyata, barang yang hendak dijemputnya itu berisi sebanyak 13,6 gram narkotika jenis sabu siap edar." (GP,2020 2/1).

Penggalan berita di atas terdapat kata 'pria' yang merupakan pilihan kata digunakan oleh penulis sebagai orang yang telah mengambil barang kiriman narkotika jenis sabu. Penggunaan kata 'pria' dalam penggalan berita di atas mempunyai makna lebih khusus,

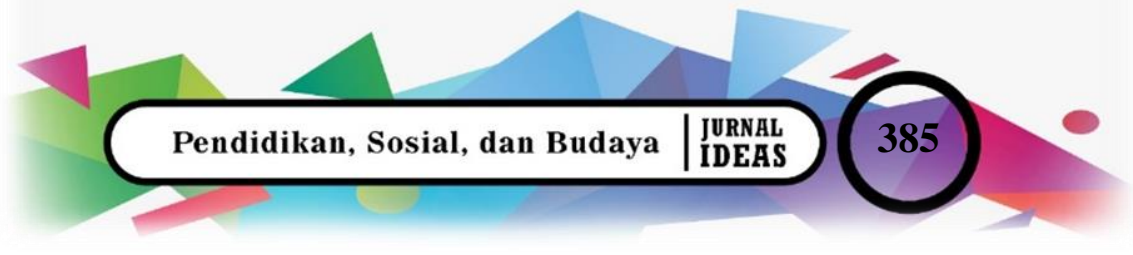


yakni laki-laki dewasa. Kata 'sabu' merupakan kata khusus yang menyampaikan makna secara langsung tentang jenis narkotika.

"Ketika kapal sandar di pelabuhan, petugas meminta agar barang dibiarkan hingga ada yang datang menjemput," (GP, 2020 2/1).

Penggalan berita di atas menggunakan kata 'sandar', yakni kata khusus yang memiliki makna tentang sangga atau menyandarkan terhadap sesuatu benda yang dapat membantu atau memberi pertolongan. Kata 'sandar' tersebut menjelaskan keadaan kapal saat sampai di pelabuhan..

"Gorontalo-Pergantian tahun baru menjadi momen yang ditunggu setiap warga Gorontalo. Ada yang merayakan dengan zikir dan doa. Namun, tak sedikit juga perayaan diwarnai dengan petasan dan kembang api. Momen haru tersebut ternyata memiliki sisi kelam, tercatat sebanyak 17 korban kecelakaan lalu lintas (Lakalantas) dan ledakan petasan di pendataan Rumah Sakit Aloe Saboe," (GP, $20202 / 1)$.

Pada kutipan berita di atas, terdapat kata zikir. Makna kata zikir adalah puji-pujian kepada Allah secara berulang-ulang; doa atau puji-pujian berlagu; perbuatan mengucapkan zikir.

"Selain kecelakaan tunggal, insiden tabrakan juga mewarnai perpisahan tahun baru,'(GP, 2020 2/1).

Penggalan kutipan berita di atas terdapat kata 'insiden' yang merupakan kata khusus, memiliki makna peristiwa atau kasus tabrakan yang sudah terjadi.

Kata-kata khusus seperti pada data oknum, pria, sabu, sandar, zikir, kelam, insiden merupakan kata yang ditulis pada berita di harian Gorontalo Pos. Kata-kata tersebut juga menunjukan bahwa pemilihan diksi dalam kalimat-kalimat berita kriminal selalu menggunakan kata yang ringkas. Hal tersebut seperti pendapat Rosidi (2009: 26) yang mengatakan bahwa salah satu ciri bahasa jurnalistik adalah harus menggunakan kata yang ringkas. Penggunaan kata 'ringkas' yang dimaksud yaitu dalam dunia jurnalistik, penulis harus hemat kata. Penggunaan kata-kata yang mubazir harus dihilangkan. Secara mendasar bisa dikatakan dengan menggunakan kata yang sedikit mungkin, bisa mewakili kalimat atau kata yang panjang dengan prinsip economy of words atau hemat kata.

3. Kata Populer

Kata populer merupakan kata yang sering digunakan oleh orang banyak dalam berkomunikasi maupun hal lainya. Berdasarkan dari hasil analisis data yang telah 
Volume: 6

Nomor : 4

Bulan : November

Tahun : 2020

dilakukan dalam penggunaan diksi pada berita kriminal terdapat kata populer yang digunakan. Penggunaan kata populer dalam berita kriminal yakni sebagai berikut.

"Hingga kini polisi masih mendalami perkara tersebut, RM belum ditetapkan sebagai tersangka," (GP, 2020 2/1).

Pada kutipan di atas terdapat kata 'tersangka' yang merupakan kata populer sering digunakan oleh pihak kepolisian dalam menyebutkan seseorang yang diduga bersalah berdasarkan keterangan saksi atau pengakuannya sendiri akibat melakukan kejahatan maupun melanggar hukum negara.

"Awalnya polisi menerima laporan perihal adanya kapal penumpang dari Pagimana, Sulawesi Tengah, yang akan bersandar di Pelabuhan Penyeberangan Gorontalo. Di dalam kapal itu diduga membawa barang yang mencurigakan. Barang tersebut dikirim orang tak dikenal," (GP, 2020 2/1).

Pada kutipan berita di atas, terdapat kata 'laporan' yang merupakan kata populer dan sering digunakan dalam berkomunikasi sehari-hari untuk melaporkan informasi penting telah terjadi salah satunya melapor kepada pihak berwajib. Kata 'barang'juga sebagai kata populer untuk menyebutkan segala sesuatu yang berhubungan dengan benda umum, seperti semua perkakas rumah, perhiasan, dan sebagainya.

"Barang bukti sabu mencapai 30 gram dan ganja 400 gram, dari keseluruhan kasus tersebut sudah mampu diselesaikan aparat kepolisian," (GP, 2020 2/1).

Pada penggalan berita di atas terdapat kata 'kasus' yang termasuk kata populer sering digunakan dalam lingkungan pengadilan untuk penyebutan suatu masalah yang terjadi kepada seseorang terkait perbuatan yang melanggar hukum. Kata kasus lebih sering digunakan dalam penyebutan suatu perkara atau masalah.

"Gorontalo-Pergantian tahun baru menjadi momen yang ditunggu setiap warga Gorontalo. Ada yang merayakan dengan zikir dan doa. Namun, tak sedikit juga perayaan diwarnai dengan petasan dan kembang api," (GP, 2020 2/1).

Pada kutipan di atas, terdapat penggalan berita yang menggunakan kata 'momen' yang sering digunakan untuk menyebutkan waktu yang spesial dalam kehidupan seseorang. Kata 'momen' selalu identik dengan kebahagiaan saat merayakan di hari yang menjadi istimewa danditunggu-tunggu oleh semua orang.

"Di media sosial facebook, grup lokal Portal Gorontalo banyak mem-posting kecelakaan lalu lintas. Korban terdiri dari anak muda hingga orang tua," (GP, 20202/1).

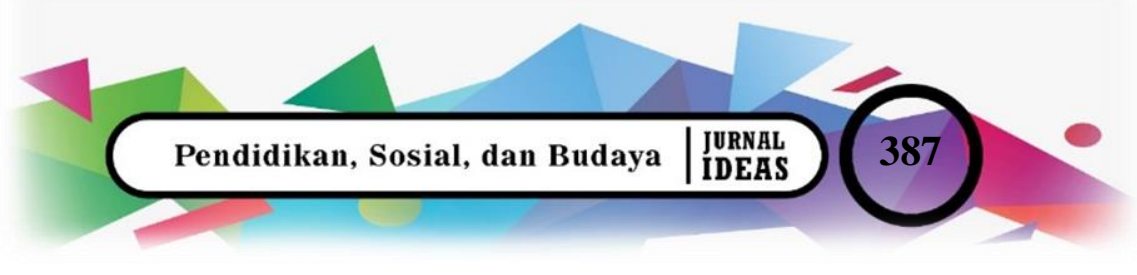


Pada kutipan di atas, terdapat kata 'korban' yang menjadi kata populer di kalangan masyarakat. Kata tersebut digunakan untuk menyebutkan orang yang telah mendapatkan musibah atau suatu kejadian menimpanya. Kata 'korban' sering dikaitkan dengan kecelakaan. Peristiwa kecelakaan yang mengalami luka parah ataupun meninggal itu disebut sebagai korban.

Kata-kata tersebut seperti tersangka, laporan, barang, kasus, momen, dan korban merupakan kata populer yang ada dalam berita. Penulisan kata populer dalam berita juga harus disesuaikan dengan bahasa yang mudah untuk dipahami dari berbagai kalangan mana saja. Seperti pendapat Keraf (2005: 105), kata-kata populer selalu dipakai dalam berkomunikasi sehari-hari, baik antara mereka yang berada di lapisan atas maupun antara mereka yang berada di lapisan bawah, atau sebaliknya. Kata-kata tersebut dikenal dan diketahui oleh seluruh lapisan masyarakat sehingga dinamakan kata populer.

4. Jargon

Jargon merupakan kata yang digunakan oleh kelompok tertentu bersifat khusus atau rahasia, bahkan orang lain tidak mengetahui maknanya. Berdasarkan dari hasil analisis data yang telah dilakukan dalam penggunaan diksi pada berita kriminal, terdapat beberapa jargon yang digunakan. Penggunaan kata jargon dalam berita kriminal adalah sebagai berikut.

"Setelah perbuatan curanmor yang dilakukan keduannya sejak minggu (05/01/2019) sekitar pukul 09.30 WITA. Tak sampai sepekan, polisi berhasil mengungkap pelaku kasus pencurian sepeda motor merek Honda Vario warna hitam putih dengan nomor polisi DM 2075 HR milik Ishak Djakani tersebut," (GP,2020 11/1).

Penggalan berita di atas terdapat kata 'curanmor', jargon dari penulis berita yang berarti pencurian motor, istilah tersebut sering dituliskan oleh jurnalis kepada pembaca di dalam berita untuk mengatakan secara tidak langsung terkait pencurian motor.

"Gorontalo-Meski selalu ditertibkan, para gelandangan dan pengemis masih marak di Gorontalo. Gepeng nampaknya tidak pernah jera dan masih melakukan aktivitas meminta-minta," (GP, 2020 30/1).

Penggalan berita di atas, terdapat kata 'gepeng' yang merupakan istilah dari gelandangan dan pengemis. Kata 'gepeng' menjadi jargon atau pemilihan kata yang digunakan oleh jurnalis dalam menyebutkan orang yang sering meminta-minta kepada orang lain dipinggir jalan atau disebut pengemis. 
Volume: 6

Nomor : 4

Bulan : November

Tahun : 2020

"Honda Brio Hilang di Depan Warkop" (GP, 2020 13/1).

Pada kutipan judul berita di atas, terdapat penggunaan kata 'warkop' sebagai pilihan kata untuk membuat judul semakin menarik untuk di baca. Kata 'warkop' yang berarti warung kopi yang digunakan di kalangan remaja untuk menyebutkan tempat berkumpul dan minum kopi secara bersama-sama.

"Sasaran operasi rutin yakni, miras, prostitusi, dan penyakit masyarakat lainnya.

Penginapan, kos-kosan dan hotel menjadi tempat yang dikunjungi aparat kepolisian" (GP, 2020 27/1).

Pada kutipan berita di atas, terdapat kata 'miras'. Pemilihan kata tersebut menjadi jargon yang sering digunakan para jurnalis atau sekelompok pemuda yang sering mabuk-mabukan untuk menyebutkan minuman keras.

"Kontak kunci dan warna motor dirubah agar tidak dicurigai. Motor kemudian dipasarkan secara daring menggunakan media sosial.Tak hanya itu,ternyata tersangka sudah empat kali melakukan aksi pencurian motor,” (GP, 2020 31/1).

Pada penggalan berita di atas terdapat kata 'daring'. Kata tersebut menjadi jargon di kalangan pendidikan atau kelompok tertentu yang sering digunakan untuk menyebutkan tentang sesuatu yang ada dalam jaringan.

"Informasi yang berhasil dihimpun dari warga yang berada di lokasi kejadian, insiden lakalantas itu terjadi sekitar pukul 06.30 WITA. Sebelum kecelakaan, Ajay yang mengendarai sepeda motor Honda jenis PCX dengan plat nomor DM 2189FG, berjalan dari arah Kecematan Tibawa menuju ke arah Kecamatan Limboto," (GP, 2020 30/1).

Pada penggalan berita di atas, terdapat kata 'lakalantas' merupakan istilah dari kecelakaan lalu lintas. Pemilihan kata tersebut digunakan jurnalis sebagai jargon dari pihak kepolisian untuk menyebutkan tentang peristiwa kecelakaan lalu lintas yang sering terjadi di masyarakat.

Penggunaan kata jargon oleh penulis dalam berita kadang sulit dipahami pembaca jika tidak membaca berita secara keseluruhan karena penulis menggunakan bahasa yang rahasia. Hal itu seperti pendapat Keraf (2005: 115), jargon diartikan sebagai kata-kata teknis atau rahasia dalam suatu bidang tertentu, bidang seni, perdagangan, kumpulan rahasia, atau kelompok-kelompok khusus lainnya. 


\section{Makna Diksi dalam Berita Kriminal Koran Harian Gorontalo Post}

1. Makna Konotatif

Makna konotatif adalah makna yang muncul karena adanya nilai rasa dari orang yang menggunakan kata-kata tersebut. Dalam penelitian ini, terdapat penggunaan makna konotatif dalam berita kriminal koran harian Gorontalo Post. Makna kata konotatif dalam berita kriminal adalah sebagai berikut.

"Gorontalo-Keterlibatan oknum Aparatur Sipil Negara (ASN) dalam peredaran dan penyalahgunaan narkoba di Gorontalo tidak pernah ada habisnya. Padahal, ancaman hukuman mati bagi pengedar narkoba sudah terbukti. Namun sayang, hal itu tak membuat jera oknum-oknum perusak bangsa tersebut," (GP, 20202/1).

Penggalan berita di atas memiliki makna konotatif yang terdapat pada kata 'sayang' tentang perbuatan yang tidak menghiraukan oleh para pelaku peredaran narkoba di Gorontalo. Kata 'sayang' tersebut bukan untuk memberikan kasih sayang kepada para pelaku, melainkan menunjukkan rasa kecewa terhadap tingkah laku terkait ASN yang terlibat dalam penyalahgunaan narkoba. Masih banyak pelaku yang melanggar meski akan mendapatkan hukuman mati.

"Gorontalo-Seorang ayah seharusnya menjadi pelindung bagi anaknya. Namun, lain halnya dengan pria inisial HL (25) warga Kecamatan Wonosari, Kabupaten Boalemo yang diduga tega merenggut kesucian anak tirinya sendiri," (GP, 20204/1).

Penggalan berita di atas memiliki makna konotatif yang terdapat pada kata 'merenggut kesucian'. Kata merenggut yang dimaksud adalah mengambil hak korban secara terpaksa, sedangkan kata kesucian menunjukkan tentang keperawanan. Penggunaan makna konotatif pada kata merenggut kesucian untuk menyampaikan makna secara tidak langsung terkait hilangnya keperawanan yang dimiliki korban.

"Lesti, balita di Desa Wonggahu, Kecamatan Paguyaman ditemukan tewas mengapung di saluran drainase desa setempat, Senin (6/1)," (GP, 2020 7/1).

Kutipan berita di atas memiliki makna konotatif yang terdapat pada kata tewas memiliki makna tentang meninggalnya balita di Desa Wonggahu. Kata tewas merupakan makna konotatif dituliskan untuk menambah nilai rasa bagi pembaca saat membaca berita.

"Pohuwato-Pergaulan bebas di kalangan remaja bahkan anak di bawah umur pada zaman sekarang patut diwaspadai para orang tua. Pasalnya, jika tidak terkontrol, maka tentu hal ini mengakibatkan semakin banyaknya anak di bawah umur yang kehilangan keperawanannya, bahkan hingga hamil di luar nikah, seperti yang dialami salah seorang siswi di salah satu Sekolah Menengah Pertama (SMP) yang 
Volume: 6

Nomor : 4

Bulan : November

Tahun : 2020

ada di Kabupaten Pohuwato terpaksa harus kehilangan mahkota berharganya," (GP, 2020 10/1).

Penggalan berita di atas memiliki makna konotatif yang terdapat pada kata 'kehilangan mahkota'. Kata 'kehilangan mahkota' yang dimaksud adalah hilangnya harga diri korban yang ditandai pada kata 'mahkota' yang menunjukan keperawanan yang dimliki siswi tersebut (korban).

"Setelah diinterogasi oleh keluarganya, korban pun akhirnya buka mulut. Ia menceritakan perihal hubungannya dengan AL. Tak terima dengan hal itu, pihak keluarga pun akhirnya melayangkan laporan dugaan pencabulan ke polisi," (GP,2020 10/1).

Penggalan berita di atas memiliki makna konotatif yang terdapat pada kata 'buka mulut' yang memiliki arti bahwa korban telah menceritakan semua kejadian yang telah dialaminya. Kata 'buka mulut' bukan berarti hanya membuka mulut lebarlebar,melainkan memiliki makna konotatif tentang sesuatu yang telah disembunyikan korbankemudian memberikan penjelasan kepada keluarga korban apa yang sebenarnya terjadi.

Penulisan kata sayang, merenggut kesucian, tewas, kehilangan mahkota, dan buka mulut merupakan makna konotatif dalam berita berkaitan dengan nilai rasa untuk membuat isi berita menarik dibaca orang banyak. Seperti halnya pendapat Chaer (2014: 292), makna konotatif adalah makna lain yang "ditambahkan" pada makna denotatif yang berhubungan nilai rasa dari orang atau kelompok orang menggunakan kata tersebut.

\section{Makna Leksikal}

Makna leksikal merupakan makna yang sebenarnya terdapat pada kata dan mudah dipahami oleh pembaca maupun pendengar. Makna kata leksikal dalam berita kriminal adalah sebagai berikut.

"Informasi yang dirangkum Gorontalo Post, penangkapan terhadap RM dilakukan saat pria berbadan ramping ini ketika hendak mengambil barang kiriman di pelabuhan penyebarangan kota Gorontalo. Ternyata, barang yang hendak dijemputnya itu berisi sebanyak 13,6 gram narkotika jenis sabu siap edar," (GP,20202/1).

Penggalan berita di atas memiliki makna leksikal pada kata 'ramping'yang memiliki makna tentang badan yang kecil atau langsing. Kata 'ramping' merupakan ciri-ciri badan yang dimiliki pelaku RM yang dituliskan dalam berita.

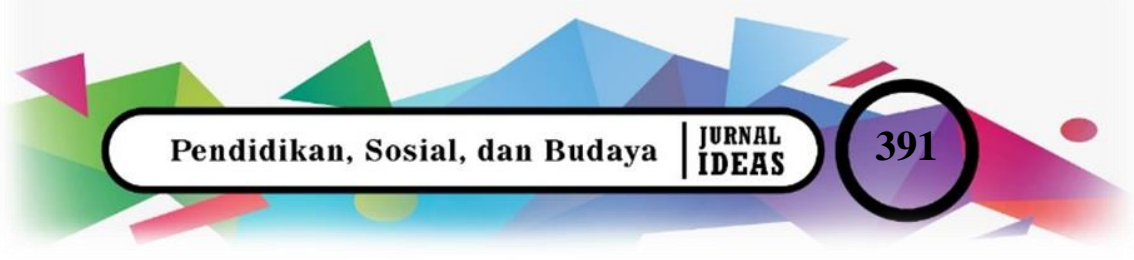


"Korban ditemukan warga pukul 16:25 dan langsung dievakuasi petugas ke pukesmas terdekat. Petugas sempat menawarkan kepada keluarga agar melakukan otopsi guna penyelidikan lebih dalam terkait kematian korban, namun pihak keluarga menolak. Jenazah korban langsung di bawa orang tua kerumah duka untuk dikebumikan" (GP, 2020 3/1).

Pada penggalan peristiwa dalam berita di atas terdapat makna leksikal. Hal tersebut terdapat pada kata 'jenazah' yang memiliki makna tentang badan seseorang yang tidak bernyawa lagi atau meninggal.

"Saat ditemukan, korban menggunakan kaos warna hitam dan celana jeans warna biru. Selain itu, luka lecet dimata kiri dengan ukuran besar, serta belatung, diduga korban meninggal sejak Rabu (1/1)" (GP, 2020 4/1).

Pada kutipan berita di atas, terdapat kata 'lecet' pada kalimat "luka lecet dimata kiri dengan ukuran besar serta belatung". Kata 'lecet' berarti terlepas kulitnya, sedangkan kata 'belatung' memiliki makna leksikal tentang suatu binatang kecil, seperti ulat yang sering ada pada sesuatu sudah membusuk.

"Menurut Natsir, kejahatan narkoba tergolong kejahatan yang tingkatnya luar biasa. Proses penyelundupannya terorganisir. Karena itu, untuk mengatasinya juga harus serius," (GP, 2020 8/1).

Pada kutipan berita di atas memiliki makna leksikal terdapat pada kata 'narkoba' yang memiliki arti tentang obat-obatan terlarang dan dapat merusak organ tubuh jika dikonsumsi.

"Antara tersangka dan korban sendiri memang telah menjalani hubungan pacaran selama dua bulan. Sebelumnya, tersangka AL yang diketahui adalah petani itu mengaku akan bertanggung jawab kepada korban jika terjadi hal-hal yang diluar dugaan," (GP, 2020 10/1).

Penggalan informasi di atas terdapat kata 'petani' yang menjadi pekerjaan tersangka AL pada kasus pemerkosaan. Kata'petani'memiliki makna leksikal tentang suatu pekerjaan yang kesehariaannya bekerja di ladang atau sawah.

Penggunaan kata ramping, jenazah, lecet, belatung, narkoba, dan petani merupakan makna leksikal dalam penulisan berita agar pembaca lebih mudah memahami makna kata atau informasi yang disampaikan di dalam berita. Seperti pendapat Waridah (2013: 300), makna leksikal adalah makna suatu kata sebelum mengalami proses perubahan bentuk. Makna tersebut masih murni mempunyai arti sesungguhnya dan belum terjadi tambahan-tambahan makna dalam kata. 


\section{Makna Gramatikal}

Makna gramatikal adalah kata yang mempunyai makna sering berubah-ubah karena adanya pengimbuhan dalam kata, seperti afiksasi, reduplikasi, komposisi atau kalimatisasi. Makna kata gramatikal dalam berita kriminaladalah sebagai berikut.

“Gorontalo-Keterlibatan oknum Aparatur Sipil Negara (ASN) dalam peredaran dan penyalahgunaan narkoba di Gorontalo tidak pernah ada habisnya. Padahal, ancaman hukuman mati bagi pengedar narkoba sudah terbukti. Namun sayang, hal itu tak membuat jerah oknum-oknum perusak bangsa tersebut," (GP, 20202/1).

Pada kutipan berita di atas terdapat pengulangan kata 'oknum-oknum' yang merupakan hasil dari reduplikasi seluruh dari bentuk dasar/kata oknum, pengulangan kata tersebut memiliki makna tentang banyaknya orang yang menjadi pelaku dalam peredaran narkoba di Gorontalo.

"Terbungkus dengan pakaian dalam dan celana pendek,bayi itu terapung dengan helem berwarna merah ketika ditemukan Yusuf di kelurahan Molosipat, kecamatan Sipatana," (GP, 2020 2/1).

Penggalan kutipan berita di atas menggunakan kata 'terbungkus' dan 'terapug' yang mempunyai makna gramatikal. Kata 'terbungkus' dari kata dasar bungkus, kemudian ditambahkan dengan prefiks ter- sehingga mempunyai makna sesuatu yang sudah dilapisi dengan bahan lain, seperti pakaian dan celana pendek yang dipakai si bayi untuk membuangnya di sungai. Kata dasar 'apung' yang diimbuhkan prefiks termemiliki makna sesuatu yang dibuang di dalam air, maka akan mengambang tidak tenggelam dalam air.

"Sementara itu dari rentetan kasus pembuangan bayi di Gorontalo, baru satu yang berhasil diungkap Polres Boalemo yakni di Kabupaten Boalemo pada 22 Juli2019 lalu," (GP, 2020 3/1).

Pada kutipan di atas, terdapat kata 'rentetan', kata dasar rentet yang diakhiri dengan sufiks -an yang memiliki makna gramatikal tentang deretan atau rangkaian yang telah terjadi dalam kasus pembuangan bayi di daerah Gorontalo.

"Akibat kejadian tersebut, bentor yang dikendarai kedua warga Kelurahan Donggala, Kecamatan Kota Barat, Kota Gorontalo itu terpental hingga beberapa meter. Keduanya mengalami luka-luka di sejumlah anggota tubuh mereka dan dilarikan ke rumah sakit terdekat, yakni RSUD MM Dunda Limboto," (GP, 20203/1).

Pada kutipan berita di atas terdapat kata'terpental', kata dasar pental yang diimbuhkan dengan prefiks ter- memiliki makna gramatikal, yang berarti terlempar sangat jauh hingga terguling-guling. Sementara itu, 'luka-luka' merupakan hasil dari 
pengulangan kata bentuk dasar luka yang memiliki makna tentang banyaknya lecet pada kulit karena tabrakan yang telah terjadi.

"Parahnya lagi, kejadian yang menimpa Bunga, bukan hanya dilakukan oleh sang ayah tiri saja.Akan tetapi, RP (56) warga Kecamatan Wonosari, Kabupaten Boalemo, yang merupakan tetangga Bunga turut melakukan perbuatan yang sama. Motifnya yakni dengan membujuk Bunga untuk pergi mandi di sungai bersama dengan anak-anaknya RP," (GP, 2020 4/1).

Penggalan berita di atas terdapat kata 'membujuk' dari kata dasar bujuk diimbuhkan dengan prefik mem-memiliki makna gramatikal yang berarti berusaha menyakinkan seseorang bahwa yang dikatakannya benar dan memikat hati untuk melakukan kebaikan maupun kejahatan yang dikatakan tersebut. Kata 'membujuk' pada penggalan berita sesuatu perbuatan yang akan dilakukan tentang kejahatan yang telah direncanakan dalam diri pelaku.

Penulisan kata oknum-oknum, terbungkus, terapung, rentetan, terpental, luka-luka dan membujuk penggunaan kata-kata tersebut terdapat dalam kalimat-kalimat berita kriminal yang mempunyai makna gramatikal. Menurut Chaer (2014: 290), makna gramatikal baru ada kalau terjadi proses gramatikal, seperti afiksasi, reduplikasi, komposisi, atau kalimatisasi.

\section{Pembahasannya mana?}

\section{Simpulan}

Berdasarkan dari hasil penelitian dan pembahasan, dapat disimpulkan bahwa diksi yang terdapat dalam berita kriminal koran harian Gorontalo Post, sebagai berikut.

1. Diksi yang terdapat dalam berita kriminal sangat bervariasi, seperti kata umum, kata khusus, kata populer, dan kata jargon. Kata umum merupakan kata yang memiliki cakupan makna yang luas, seperti kata pihak berwajib, rasa panik, mungil, rumah, heboh, tewas, dan lain-lain. Kata khusus yang memiliki kandungan makna yang terbatas dan tidak meluas, seperti oknum, pria, sabu, sandar, zikir, kelam, dan insiden. Kata populer sebagai kata yang sering digunakan orang banyak untuk menulis atau berkomunikasi secara langsung. Penggunaan kata populer dalam tulisan berita seperti tersangka, laporan, kasus, momen dan korban. Kata jargon adalah kata yang rahasia digunakan dalam berbagai hal, seperti menulis, salah satunya dalam menulis berita. Jargon dalam berita misalnya kata 'curanmor'yang berarti pencurian motor. Istilah tersebut sering dituliskan oleh jurnalis kepada pembaca di dalam berita untuk mengatakan secara tidak langsung terkait peneurian motor. Diksi atau pilihan kata 
Volume: 6

Nomor : 4

Bulan : November

Tahun : 2020

dalam berita telah dipakai sesuai dengan topik atau masalah yang ada dalam berita. Pemilihan kata yang tepat memberikan makna kata dalam berita tersampaikan kepada pembaca menjadi lebih jelas.

2. Makna yang terdapat dalam berita kriminal koran harian Gorontalo Post, antara lain makna konotatif, makna leksikal, dan makna gramatikal. Makna konotatif merupakan suatu makna ganda yang mempunyai arti tersendiri melalui nilai rasa dari masingmasing orang. Salah satunya dalam penulisan berita, seperti "Namun sayang, hal itu tak membuat jerah oknum-oknum perusak bangsa tersebut." Kata 'sayang' yang dimaksud bukan memberikan kasih sayang kepada pelaku, melainkan menunjukkan rasa kecewa terhadap pebuatan ASN terkait penyalahgunaan narkoba. Penggunaan makna leksikal dalam berita seperti kata 'ramping' yang memiliki makna tentang badan yang kecil atau langsing sebab makna leksikal merupakan makna yang sesungguhnya tanpa ada perubahan makna. Penulisan makna gramatikal dalam berita salah satunya kata 'rentetan' dengan kata dasar rentet yang diakhiri dengan sufiks -an memiliki makna gramatikal tentang deretan atau rangkaian yang sudah terjadi sebelumnya. Penggunaan makna kata tersebut membuat informasi yang disampaikan kepada pembaca menjadi lebih jelas.

\section{Daftar Pustaka}

Arifin, Zaenal \& Amran Tasai. (2009). CermatBerbahasaIndonesiauntuk Perguruan Tinggi. Jakarta: Akademika Pressindo.

Badara, Aris. (2012). Analisis Wacana Teori, Metode, dan Penerapannya pada Wacana Media. Jakarta: Kencana Prenada Media Group.

Chaer, Abdul. 2014. Linguistik Umum. Jakarta: Rineka Cipta.

Keraf, Gorys. (2005). Diksi dan Gaya Bahasa. Jakarta: Gramedia Pustaka Utama.

Rosidi, Imron. (2009). Menulis ... Siapa Takut?. Yogyakarta: Kanisius.

Sarwoko, Tri Adi. (2007). Inilah Bahasa Indonesia Jurnalistik. Yogyakarta: Andi Offset.

Waridah, Ernawati. (2013). EYD. Jakarta Selatan: Kawah Media. 
TE E-ISSH: 2656-940X $\mid \begin{aligned} & \text { Volume: } 6 \\ & \text { Nomor: } 4\end{aligned}$

(D) P-ISSN: 2442-367K

Nomor : 4

URL:jurnal.ideaspublishing.co.id Tahun : 2020

: November 